\title{
冷媒物性を考慮した空調設備のエネルギーシミュレーション用 個別分散空調システムモデルの開発 \\ DEVELOPMENT OF MULTI-SPLIT TYPE AIR-CONDITIONING SYSTEM MODEL FOR HVAC SYSTEM ENERGY SIMULATION BASED ON REFRIGERANTS THERMODYNAMIC PROPERTIES
}

安宅智洋*, 富樫英介**, 田辺新一*** Tomohiro ATAKU, Eisuke TOGASHI and Shin-ichi TANABE

\begin{abstract}
This study proposes methods of the multi-split type air-conditioning system model based on refrigerants thermodynamic properties that improve the computational speed reserving accuracy and extrapolability, and reduce physical parameters setting work. The purpose is to improve the quantitative performance assessment of the multi-split type air-conditioning system. The approximation method of refrigerative physical properties value using the neural network improves the computational speed. When the heat load of indoor equipment is input to the multi-split type air-conditioning system model, the amount of consumption energy is the output. It is found the proposed model can calculate approximate outputs in cases of not only JIS but other conditions.
\end{abstract}

Keywords : Multi-split Type Air-Conditioning System, Physical Simulation, R410A 個別分散空調方式, 物理シミュレーション, R410A

\section{1. 研究背景}

近年，個別分散空調方式の大規模ビルへの採用事例が増加してお り，そのエネルギー消費量が占める割合は，増加傾向にある1)。一 方で，実験室実験と現場に扔ける運転状況の違いにより，公表され ている COP等の性能が，現場での性能を表現していないのではな いかという指摘も多い。このような疑問に対して定量的な解答を与 える方法として, シミュレーションによる個別分散空調システムの 挙動の検討が挙げられる。個別分散空調システムに関しては, これ までもいくつかのモデルが提案されている2) つ)。これらのモデルは, 個別分散空調システムの構成要素の一部または全部を機器特性式で 表現する『特性モデル』と，その全てを物理式に基づいて表現する 『物理モデル』に大別することができる。

特性モデルの例としては宇田川ら，下田ら，赤司らのモデルが挙 げられる。宇田川らは冷房運転時のエネルギー消費量予測を目的と し，冷却コイルおよび凝縮機についての熱平衡と圧縮機運転特性を 基礎として，空調機仕様抒よび吹出し空気の入口状態，外気条件が 与えられた場合の, コイル処理能力, 吹出し空気出口条件, 圧縮機 所要動力などを計算するためのモデルを開発している2)。また，下 田らは, 小規模建物に扔けるエネルギー消費特性を評価するために, HASP/ACSS/8501での算法を参考にして簡易モデルを作成してい $3^{3) 4}$ 。赤司らは, 部分負荷率を求め, 入力比, 入力比補正から, システムのエネルギー消費量を算出するモデルを提案している5)。 また，我が国の代表的なエネルギーシミュレーションプログラムで
ある HASP/ACSS, 近年開発が進められている LCEM ッールなど もこれらの例と同様，特性モデルを採用している。このような特性 モデルは, 設定すべき物理パラメータは少なくて済むため, ユーザー がモデルを構築するために必要となる作業量は少なくなるという利 点がある。また, 通常, 特性式は陽的に解くことが可能で, 収束計 算が不要であるため計算速度も速い。反面, 特性式の外挿範囲にモ デルを適用することは難しい。また, 数多く存在する機種のそれぞ れに対して機器特性を用意する必要があり, 機器開発者側の負担が 大きいという問題がある。

物理モデルの例としては, 畧崎ら, 河合らのモデルが挙げられる。 嘼崎は, 冷媒の非共沸性による循環組成, 存在組成の局所的な変化 を考慮した, 冷凍サイクルの動特性把握を可能とするダイナミック シミュレーションの計算方法について報告している 個々の要素のモデルを構築し, それらを接続することによりサイク ルループ全体のモデルを構築する手法を提案している7)。このよう な物理モデルは, 計算対象の機器仕様に忠実な物理パラメータの設 定が可能であるため, 適切にパラメータが設定された場合には特性 モデルよりも高い精度が期待できるという利点がある。反面, その ような適切なパラメータを入手して設定するためにユーザー側に求 められる作業量は非常に大きい。また, 通常は, 冷媒物性計算も含 めた収束計算が必要となるため, 特性モデルに比較して計算速度は 遅くなり, 年間の空調設備のエネルギーシミュレーションという用 途に適用することは難しい。

\footnotetext{
* 久米設計 工修 (元 早稲田大学大学院)

** 早稲田大学創造理工学部建築学科 助手·工博

*** 早稲田大学創造理工学部建築学科 教授. 工博

KUME SEKKEI Co., Ltd., M. Eng.

Research Assoc., Department of Architecture, Waseda University, Dr. Eng. Prof., Department of Architecture, Waseda University, Dr. Eng.
} 
以上の背景を受け, 本研究では, 物理モデルの精度および外抻可 能性を留保しつつ, その計算速度を向上させるとともに, 定格性能 值に基づく物理パラメータの推定方法を提案することで, シミュ レーションによる個別分散空調システムの定量的性能評価を可能と することを目的とする。

\section{2. 研究方法}

前節で述べたとおり，空調設備のエネルギーシミュレーションに おいて，物理式に基づく個別分散空調システムモデルを利用するた めには，次の二つの大きな問題を解決する必要がある。

一点目の問題は, 計算速度の改善である。個別分散空調システム のモデル化のためには, 冷凍サイクルを表現する必要があり, 循環 する冷媒の圧力, 密度, 温度等の物性に関する計算は避けられない。 仮に冷媒物性を理論的に計算するとすれば，冷凍サイクルを構成す る各機器の入出力を一致させるための収束計算だけではなく, 各機 器モデルの内部で利用する冷媒物性值を求めるための収束計算が必 要となる。建築熱負荷計算と連成して年間にわたり繰り返し計算す る必要があるため, その計算時間は極めて大きくなり，問題がある。 本研究では, 収束計算が不要な冷媒物性值近似法を開発すること でこの問題を解決することとした。具体的には, 冷媒圧力およびエ ンタルピーを入力とし, 温度および密度を出力するニューラルネッ トワークを構成することで, 収束計算を行わずに高速で冷媒物性值 を近似することを可能とした。

二点目の問題は, 煩雑なパラメー夕設定作業の軽減である。特性 モデルの場合, 現実の機器と一対一に対応したモデルとはならない 可能性はあるものの, 定格の能力や消費エネルギー量など, いくつ かの項目についてパラメータを設定するのみで一応の動作が可能な モデルを得ることができる。一方, 物理モデルは全てのパラメー夕 を適正に設定した場合の再現性は高いものの，そのために必要な作 業量は大である。

本研究では，一般に入手可能な情報をもとに，モデルに設定すべ きパラメー夕を推定する方法を提案した。具体的には, まず, メー カーから開示されている技術資料に記された定格運転点での各種情 報に基づき，計算対象である個別分散空調システムの冷凍サイクル の基準点を求めた。次に, 求められた基準点における冷媒物性值を 入力および出力とし, 冷凍サイクルを構成する要素である各機器の パラメータを推定する方法を示した。また，このようなパラメータ 設定によって適正なモデルが得られたことの検証として, 定格以外 の運転点におけるモデルの出力を評価し, 外挿範囲において本モデ ルが一定の精度を確保していることを示した。

本研究で解決を図った, 以上の二つの問題と, 本研究で開発する モデルの位置づけを図 1 に示す。物理モデルの長所である精度と外 挿可能性は維持する一方, 短所である計算速度の遅さおよび煩雑な モデル構築作業については, それぞれ, 冷媒物性值高速近似法およ びパラメータ推定法の開発によって解決を図った。

3 節では冷媒物性值の高速近似法の開発について，4節では物理 モデルの構造について，5節ではパラメータ推定法について，6節 では構築されたモデルの外挿範囲に扔ける精度検証結果について記 した。

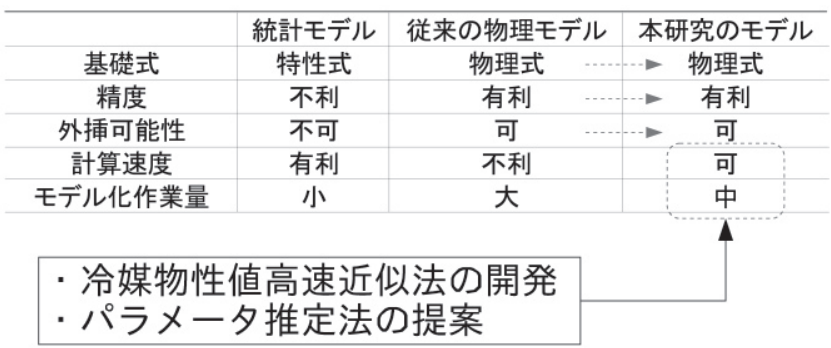

図1 本研究で開発するモデルの位置づけ

\section{3. 冷媒物性值の高速近似手法の開発}

個別分散空調システムの挙動を把握するためには, 内部を流れる 冷媒の物理的特性を知る必要がある。従って, 密度, 温度, エン夕 ルピー, 圧力等, 冷媒物性值の計算は, 冷凍サイクルを構成する個 別機器のモデル化にあたっても必須のものである。

冷媒物性值計算プログラムとしては米国 NISTによって開発され た REFPROP ${ }^{8)}$ が世界標準となっているが, これは状態方程式を反 復計算によって解き, 厳密解を求めるものである。従って, 計算速 度は遅く, また, 反復計算が正常に終了しない範囲が存在すること も指摘されている ${ }^{9)}$ 。Cleland, Charters らはそれぞれ R134a や R22 などの純粋な冷媒の近似法を提案している ${ }^{10) 11}$ 。Corberan らは R22, R134A，R407C，R410Aのモリエ線図をメッシュ状に分割し線形補 間を行うことで, 多くの冷媒状態について誤差率 $1 \%$ 以下の近似を 行ったと報告している ${ }^{12)}$ 。Guoliang らは陰的形式で冷媒近似多項式 を表現し, これらを解析的な操作で解くことで双方向の変換が可能 な冷媒近似法を提案しており， R410A に関しては平均誤差率 $0.04 \%$ であったと報告している9 。しかし，これらのいずれの報告におい ても二相域の冷媒密度の近似に関しては触れられてはいない。飽和 液線周辺では冷媒密度が上昇するため非線形性が非常に強く, 通常 の多項式では近似が困難であることが原因であると推測できる。冷 凍サイクル計算モデルにおいては, 圧縮機での質量流量計算や配管 圧損計算のために冷媒の密度情報が必要となるため, 二相域での冷 媒密度を近似する方法を確立する必要がある。

\section{1 ニューラルネットワークによる冷媒物性近似法}

ニューラルネットワークは, 特定の入出力構造を持つ素子を相互 に接続したモデルである。各素子は入力信号と結合荷重の積和を伝 達関数で変換した值を出力值にとる。素子を 3 列, 層状に並べた ネットワークである 3 層パーセプトロンは, 任意の入出力関係を有 限の素子数で近似できることが証明されているため ${ }^{13)}$, 本研究では これを用いて R410A の冷媒物性值の近似を行うこととした。図 2 に, 1 出力の場合の 3 層パーセプトロンの構造を示す。式 1 に出力 計算式を示す。本研究では式 2 で表現されるシグモイド関数を伝達 関数として利用することとした。

飽和液線および飽和蒸気線上における近似の対象は, 圧力に対す る温度, 密度, エンタルピーの值とした。飽和線上以外の領域にお ける近似の対象は, 圧力およびエンタルピーに対する温度および密 度の值とした。ただし, 冷媒の温度や密度は, 飽和液線掞よび飽和 蒸気線を境に変曲するため, 本研究では領域ごとに別個のニューラ ルネットワークを構成して近似を行った。また, 二相域の密度は飽 和液線近くで急激に上昇するため, 入力值としてはエンタルピーの 絶対值よりも, 同一圧力下における飽和液, 飽和蒸気線上のエンタ 
ルピーとの相対的な関係性の方が有効であると推測できる。従って， 同領域の密度近似のための入力として, 式 3 で定義する相対エンタ ルピー值を与えた。各状態值の近似を行うための入力を表 1 に示す。 例えば10行目は, 過冷却域の冷媒温度 $T_{s c}$ を近似するための入出力 を表しており，圧力 $P$ とエンタルピー $H$ が入力となる。

近似の対象とする学習データは, REFPROP Version 7.0を用いて 作成した。近似範囲は一般的な冷凍サイクルを包含することができ るように圧力に関して 200 3800kPa，エンタルピーに関して160〜 $540 \mathrm{~kJ} / \mathrm{kg}$ とした。近似範囲内で, 圧力を $50 \mathrm{kPa}$ ，エンタルピーを $20 \mathrm{~kJ} / \mathrm{kg}$ ごとにREFPROP で冷媒状態を求め, 学習データとした。 ただし，二相域の密度に関しては飽和液線付近で急速に值が上昇す るため, 均等メッシュ分割とはせず，式３で定義した相対エンタル ピー值が表 2 の值をとる点で密度を計算し，学習データとした。

\section{2 提案した手法の性能評価}

近似範囲内で REFPROP および近似モデルによる冷媒状態計算を 実行して比較した。例として, 密度出力值㧍よび誤差率を図 3 に示 す。各近似值の最大誤差率と平均誤差率を表 3 に示す。誤差率は正 解值である REFPROP の出力絶対值に対する比率である。飽和液線 付近の急激な密度上昇が再現できていることがわかる。温度, 密度 のいずれの領域についても平均誤差率は $0.2 \%$ 以下となった。表 4 にREFPROP および近似モデルの計算速度注1)を示す。飽和線上の

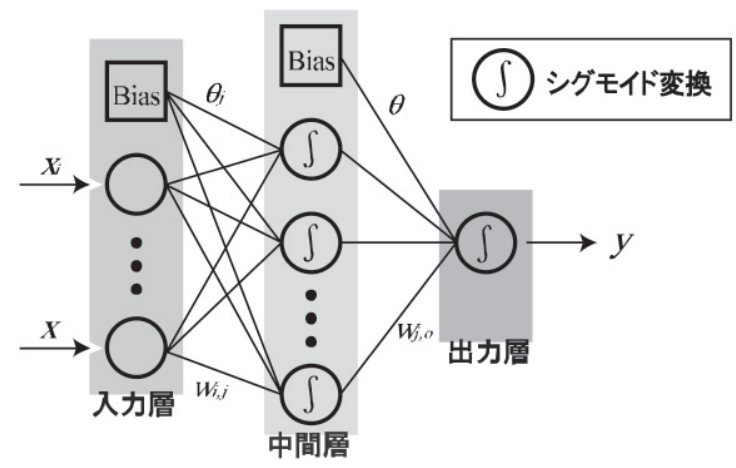

図2 3 層パーセプトロン

$$
\begin{aligned}
& y(x)=f_{s}\left\{\sum_{j=1}^{\sigma} w_{j, o} f_{s}\left(\sum_{i=1}^{\tau} w_{i, j} x_{i}+\theta_{j}\right)+\theta_{o}\right\} \\
& f_{s}(x)=\frac{2}{1+e^{-x}}-1
\end{aligned}
$$

(2)

\begin{tabular}{c|c|c|c|c|c}
\hline & $x_{1}$ & $x_{2}$ & $x_{3}$ & $x_{4}$ & $y$ \\
\hline \hline 1 & $P$ & - & - & - & $T_{s l}$ \\
\hline 2 & $P$ & - & - & - & $H_{s l}$ \\
\hline 3 & $P$ & - & - & - & $\rho_{s l}$ \\
\hline 4 & $P$ & - & - & - & $T_{s v}$ \\
\hline 5 & $P$ & - & - & - & $H_{s v}$ \\
\hline 6 & $P$ & - & - & - & $\rho_{s v}$ \\
\hline 7 & $P$ & $H$ & - & - & $T_{s c}$ \\
\hline 8 & $P$ & $H$ & $\rho_{s l}$ & $\rho_{s v}$ & $T_{t p}$ \\
\hline 9 & $P$ & $H$ & - & - & $T_{s h}$ \\
\hline 10 & $P$ & $H$ & - & - & $\rho_{s c}$ \\
\hline 11 & $P$ & $H$ & - & - & $\rho_{t p}$ \\
\hline 12 & $P$ & $H$ & - & - & $\rho_{s h}$ \\
\hline
\end{tabular}

$$
H_{r}=\frac{H-H_{s l}}{H_{s v}-H_{s l}}
$$

表2 相対エンタルピー值

\begin{tabular}{llllll}
\hline $4.7 \mathrm{E}-04$ & $2.1 \mathrm{E}-03$ & $7.6 \mathrm{E}-03$ & $2.8 \mathrm{E}-02$ & $1.0 \mathrm{E}-01$ & $3.9 \mathrm{E}-01$ \\
$9.1 \mathrm{E}-04$ & $3.2 \mathrm{E}-03$ & $1.2 \mathrm{E}-02$ & $4.4 \mathrm{E}-02$ & $1.6 \mathrm{E}-01$ & $6.0 \mathrm{E}-01$ \\
$1.3 \mathrm{E}-03$ & $4.9 \mathrm{E}-03$ & $1.8 \mathrm{E}-02$ & $6.8 \mathrm{E}-02$ & $2.5 \mathrm{E}-01$ & $9.3 \mathrm{E}-01$ \\
\hline
\end{tabular}

表 3 近似精度

\begin{tabular}{l|c|c}
\hline \multicolumn{1}{c|}{ 近似対象 } & 最大誤差率 [\%] & 平均誤差率 [\%] \\
\hline \hline 飽和線圧力 & 0.2140 & 0.0204 \\
\hline 飽和線エンタルピー & 0.0014 & 0.0003 \\
\hline 飽和線温度 & 0.7643 & 0.1082 \\
\hline 領域温度 & 0.1036 & 0.0167 \\
\hline 領域密度 & 1.9820 & 0.1461 \\
\hline
\end{tabular}

表 4 計算速度

\begin{tabular}{c|c|c|c}
\hline 近似対象 & REFPROP [msec] & 近似モデル [msec] & 速度比 [-] \\
\hline \hline 飽和線近似 & 1796.86 & 15.63 & 115.0 \\
\hline 領域近似 & 649343.75 & 1484.38 & 437.5 \\
\hline
\end{tabular}

$$
W=\eta_{v} \operatorname{Vol} \frac{\kappa}{\kappa-1} P_{\text {in }}\left\{\left(\frac{P_{\text {out }}}{P_{\text {in }}}\right)^{(\kappa-1) / \kappa}-1\right\}
$$

$W=G \Delta H_{C m p}$

$G=\eta_{v} \cdot \operatorname{Vol} \cdot \rho_{\text {in }}$

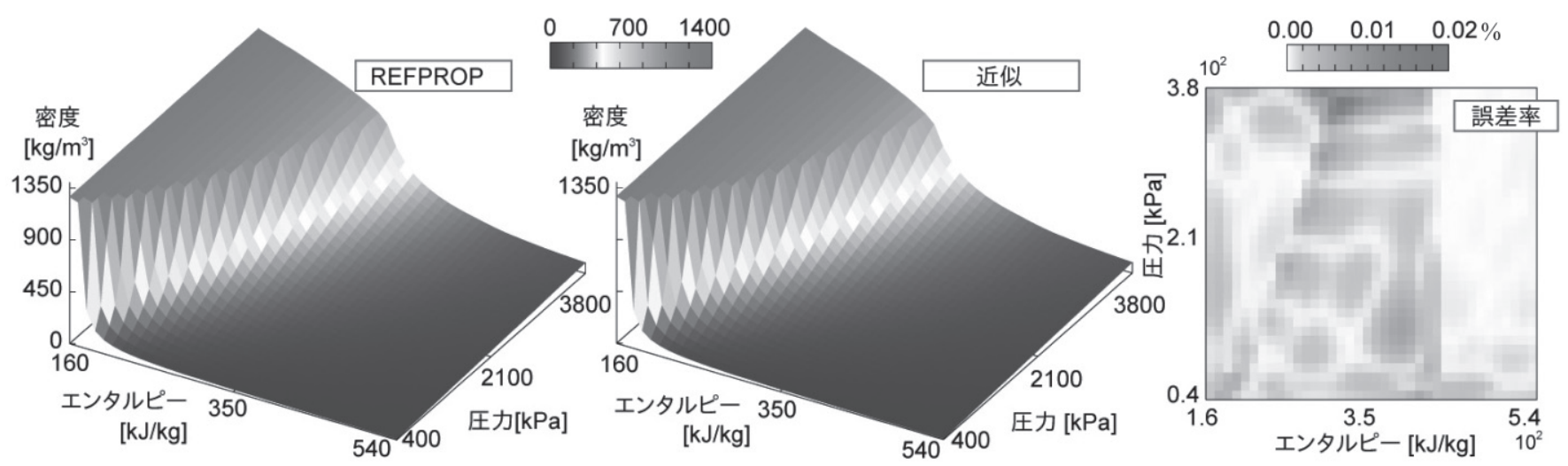

図 3 REFPROP および近似モデルによる冷媒密度出力值と誤差率 
冷媒状態に関しては 100 倍以上，その他の領域に関しては400倍以上 の速度で計算が完了していることがわかる。

以上の結果により, 十分な精度と速度での計算が可能と確認され たため，本報の 5 節および 6 節の検討の際には，提案した冷媒物性 值近似手法を用いて計算を行った。

\section{4. 冷媒物性を考慮した個別分散空調システムのモデル化}

冷凍サイクルを構成する主要な機器としては, 圧縮機, 凝縮機, 蒸発器が挙げられる。これらの機器の連結のあり方は様々な可能性 があり，一概には言えない。例えば多段圧縮型の場合は複数台の圧 縮機から構成され, 個別分散空調機の場合は複数台の蒸発器および 膨張弁が並列に接続される。従って，予め特定の連結状態に特化し てコード化することはプログラムの再利用性を低下させることにな る。そこで本研究では，オブジェクト指向プログラムにおけるクラ スとして個別の機器モデルを開発した後，冷凍サイクルを表現する 上位のクラスでこれらの機器クラスを連結させるという方法をとっ た。室外機と室内機が 1 対 1 対応のパッケージ型空調機のモデル化 に関しては河合ら゙による報告があり，本研究においても個別の機 器は同様の基礎式に基づいてモデル化を行った。

\section{1 圧縮機モデル}

式 4〜 6に圧縮機の基礎式を示す。圧縮機による圧縮仕事は式 4 で示される様に出入口圧力の関数である。冷凍サイクル内を循環す る冷媒の質量流量は圧縮機のピストン押しのけ量により定まり, 式 6 で表現される。ここで冷媒密度 $\rho_{\text {in }}$ は圧縮機入口冷媒圧力および エンタルピーから冷媒状態方程式を解くことで求められる。これに 関しては，前述の泠媒物性值近似法を利用して計算を行った。

\section{2 凝縮器・蒸発器モデル}

式 $7 〜 8$ に凝縮器および蒸発器の基礎式を示す。流体間での熱移 動の方向は異なるが, いずれも空気対冷媒の熱交換器として同様の 方法で解くことができる。本研究では対数平均温度差法を利用して 解くこととした。式 8 に対数平均温度差の定義を示す。ただし, 冷 媒に関しては熱交換の過程において状態変化が生ずる可能性がある ため，単純に式 7 を適用することはできない。そこで，熱交換器内 での冷媒の状態に応じて領域を液相, 二相, 気相にわけ, 各々につ いて式 7 および式 8 を解くことで交換熱量を計算した。この問題は, 入口の冷媒㧍よび空気のエンタルピーが既知の場合, 出口の冷媒エ ンタルピーを未知変数とすることで反復計算により解くことができ る。ただし, 簡略化のため, 熱交換器内では圧力変化が無いと仮定 して計算する。例として, 冷媒入口状態が気体で凝縮機による冷却 を行う場合を想定して計算法を以下に記す。

計算フローを図 4 に示す。下線部は前節の冷媒物性近似手法を適 用した箇所である。このフローは二相域で熱交換が終了する場合で あるが，冷媒が過冷却となる場合についても同様の方法で計算が可 能である。熱交換器の伝熱面積を $A$ とし, その面積の内, 過熱状 態にある冷媒が占める面積割合を $R_{s h}$ とする。同様に二相の割合, 過冷却の割合をそれぞれ $R_{t p}, R_{s c}$ とする。熱交換器内で圧力損失が 生じないとすれば, 式 7 を利用して飽和蒸気線上のエンタルピーと 入口冷媒エンタルピーとの差分から, 全冷媒蒸気が二相状態に変化 するために必要な伝熱面積 $A \times R_{\text {sh }}$ を計算することができる。仮に 伝熱面積割合 $R_{\text {sh }}$ が1.0以上の值であったとすると，全冷媒が二相へ

$$
\begin{aligned}
& Q=\left\{\begin{array}{l}
A R K \Delta \theta \\
G_{\text {ref }} \Delta H_{\text {ref }} \\
G_{\text {air }} \Delta H_{\text {air }}
\end{array}\right. \\
& \Delta \theta=\frac{\left(T_{\text {1in }}-T_{\text {2in }}\right)-\left(T_{\text {1out }}-T_{\text {2out }}\right)}{\ln \left(\left(T_{\text {1in }}-T_{2 i n}\right) /\left(T_{\text {1out }}-T_{\text {2out }}\right)\right)}
\end{aligned}
$$

表 5 モデルのパラメータ一覧

$$
\text { パラメータ }
$$

熱交換器面積 $\left[\mathrm{m}^{2}\right]$ 熱通過率 $\left[\mathrm{W} /\left(\mathrm{m}^{2} \mathrm{~K}\right)\right]$ 過熱度 $\left[{ }^{\circ} \mathrm{C}\right]$ 圧縮機ピストン押しのけ量 $\left[\mathrm{m}^{3} / \mathrm{h}\right]$ 過椧却度 $\left[{ }^{\circ} \mathrm{C}\right]$ 熱交換器最大風量 $[\mathrm{CMH}]$ 高圧上下限值 $[\mathrm{kPa}]$ 蒸発温度上下限值 $\left[{ }^{\circ} \mathrm{C}\right]$ 回転数上下限值 [rps]

表 6 モデルの入出力変数一覧

\begin{tabular}{c|l}
\hline \multicolumn{1}{|c}{ 入力変数 } & \multicolumn{1}{c}{ 出力変数 } \\
\hline \hline 外気条件 & 圧縮仕事量 $[\mathrm{W}]$ \\
(乾球温度, 絶対湿度) & 熱交換器冷媒流量 $[\mathrm{kg} / \mathrm{s}]$ \\
公内空気条件 & 除去熱量 $[\mathrm{W}]$ \\
(乾球温度, 絶対湿度) & 未処理負荷 $[\mathrm{W}]$ \\
各室内機の熱負荷 $[\mathrm{W}]$ & 蒸発温度 $\left[{ }^{\circ} \mathrm{C}\right]$, 低圧圧力 $[\mathrm{kPa}]$ \\
& 凝縮温度 $\left[{ }^{\circ} \mathrm{C}\right]$, 高圧圧力 $[\mathrm{kPa}]$ \\
& 圧縮機回転数 $[\mathrm{rps}]$ \\
\hline
\end{tabular}

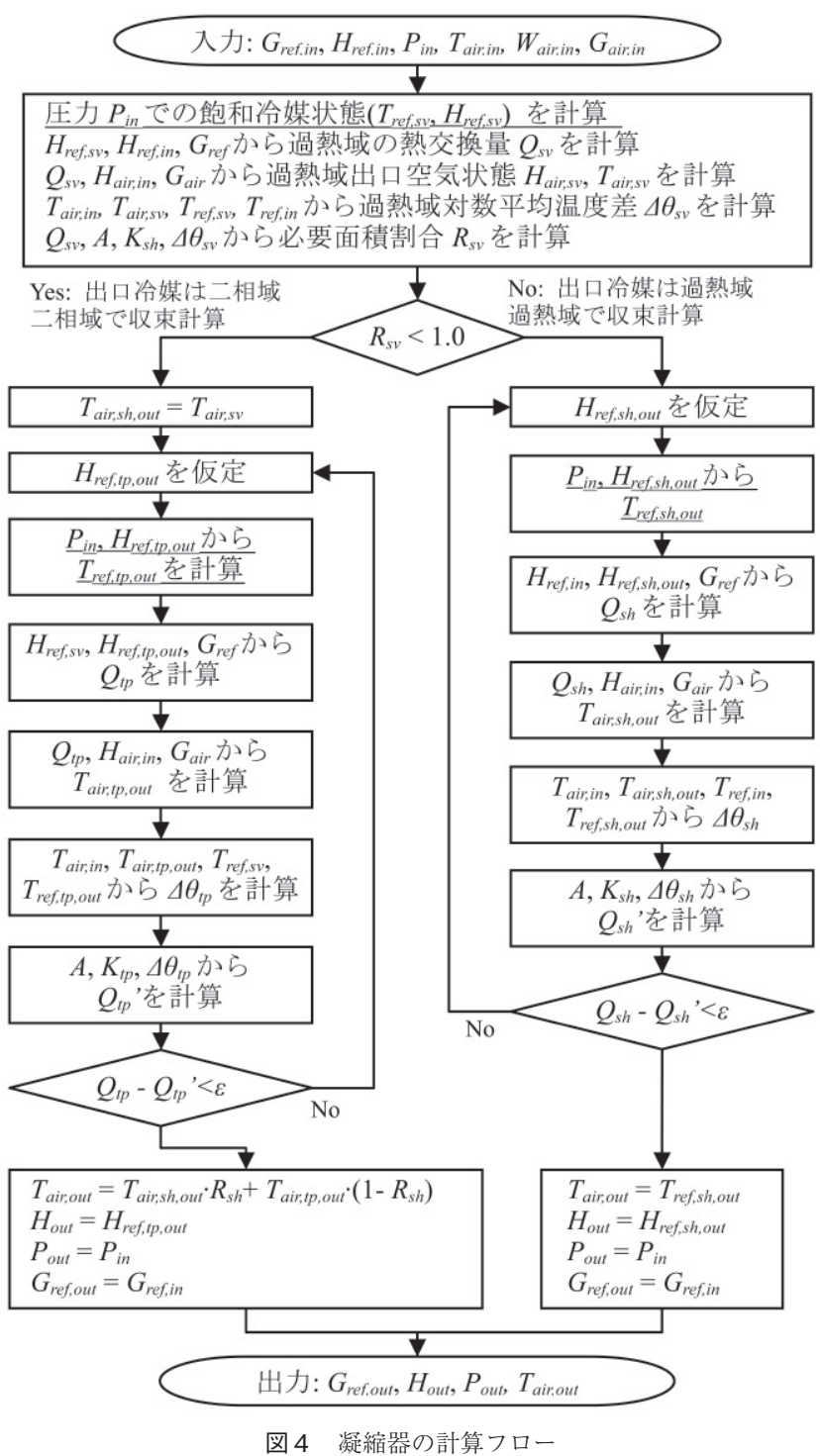

図 4 凝縮器の計算フロー 
状態変化できなかったということになり, 過熱域で式 7 を収束計算 で解く。逆に伝熱面積割合 $R_{s h}$ が1.0未満の場合は全冷媒が二相化す る。この場合には式 7 と飽和液線掞よび飽和蒸気線上のエンタル ピーの差分を利用して全冷媒が液化するために必要な伝熱面積 $A \times$ $R_{t p}$ を求める。以下, 同様の手順を繰り返し, 冷媒出口エンタルピー を計算する。なお, 蒸発器を計算する場合は, 湿り空気は一定の相 対湿度線に沿って絶対湿度が降下すると仮定した。

\section{3 個別分散空調システムモデル}

1) 入出力変数拉よびパラメータ

表 5 にモデルのパラメータ一覧を示す。高圧上下限值，蒸発温度 上下限值, 回転数上下限值の範囲内で制御を行い, 出力を計算する 仕様とした。表 6 にモデルの入出力変数一覧を示す。エネルギー消 費量の計算を目的としているため, 熱負荷と外気抢よび室内空気条 件を入力とし，圧縮仕事量を出力とするモデルとした。また，入力 条件に応じて圧縮機回転数や高圧・低圧をモデル内部で調整し, こ れらについても出力することとした。このような入出力とする場合, 入力条件によっては熱負荷の除去が不可能な場合がある。そこで, 計算の安定化のために，過負荷となり指定された熱負荷が処理でき ない場合には熱量の不足分を未処理負荷として出力する仕様とし た。

2) 仮定事項

計算にあたり，以下の仮定を置いた。
・蒸発温度は室内機で未処理負荷が発生しない範囲で, できる限り 高く調節される

·圧縮機の出口圧力は凝縮器で未処理負荷が発生しない範囲で, で きる限り低く調節される

・インバー夕回転数は蒸発器で未処理負荷が発生しないだけの冷媒 流量を確保するように調節される

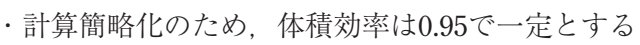

·各室内機への泠媒流量は, 各室内機熱負荷の比率とする。例えば, $1 \mathrm{~W}, 2 \mathrm{~W}, 3 \mathrm{~W}$ の熱負荷がある場合には, 各室内機への冷媒流量 は $1: 2: 3$ となる

3）計算フロー

図 5 に冷凍サイクルの計算フローを示す注2)。下線部は冷媒物性 近似手法の適用箇所である。蒸発温度の収束計算と凝縮圧力の収束 計算とに大きく分けることができ, 凝縮圧力の収束計算は蒸発温度 の収束計算に内包される入子状の構造となっている。

まず，蒸発温度 $T_{E v p, i n}$ を最低に設定する。ここで，過熱度制御の 設定值は入力条件であるため, 圧縮機の入口冷媒状態が確定する。 仮に最低蒸発温度で熱負荷が処理可能であるならば, より高い蒸発 温度の泠凍サイクルが成立する。逆に最低蒸発温度で熱負荷が処理 できない場合には過負荷であるため，未処理負荷を計上する。

圧縮機入口冷媒状態が確定すると, 凝縮器側の計算が可能となる。 まず，凝縮圧力 $P_{C n d, i n}$ を最大に設定する。過冷却度は入力条件とし

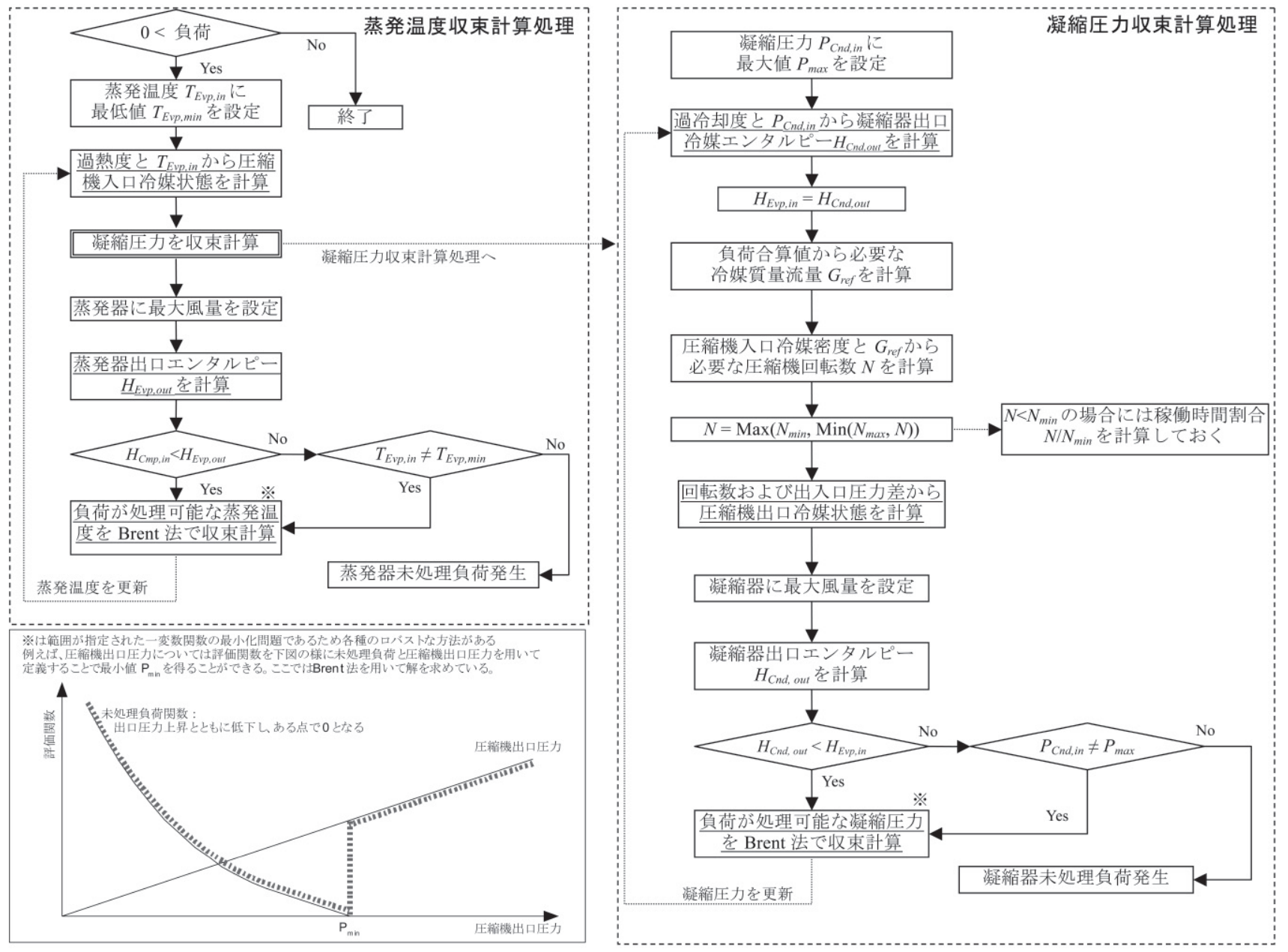

図 5 モデル計算フロー 
て与えられているため, 仮定した圧力値と合わせて凝縮器出口エン タルピーを計算することができる。凝縮器出口エンタルピー＝蒸発 器入口エンタルピーとすれば, 蒸発器出入口エンタルピーが明らか となるため, 各室内機で必要な冷媒質量流量 $G_{r e f}$ を計算することが できる。この冷媒流量合算值を実現するように圧縮機の回転数 $N$ を調整する。なお，圧縮機の入口冷媒状態は既に確定している。最 小回転数を下回る場合には最低負荷率で発停状態になったとみな し，最小回転数で計算を行った後に稼動時間割合を乗ずることとす る。逆に最大回転数を上回る場合には最大回転数を設定する。この 場合には冷媒質量流量の不足により蒸発器側で未処理負荷が生ずる ことになる。以上により, 圧縮機の回転数, 出入口圧力差, 冷媒質 量流量が明らかとなったため, 式 4 と式 5 から圧縮仕事量と出入口 エンタルピー差が計算でき，圧縮機出口冷媒状態が計算できる。圧 縮機出口冷媒状態 $=$ 凝縮器入口冷媒状態とし, 凝縮器が出口エンタ ルピーを実現できるかを確認する。実現できない場合には過負荷状 態となっている。最大圧力で過負荷となる場合には未処理負荷を計 上する。逆に負荷が処理可能な場合には凝縮圧力を下げていく。こ れは凝縮圧力を未知変数とした，範囲指定のある一次元関数誤差最 小化問題であり, Brent 法, 黄金探索法などのロバストな解法が存 在する。本研究では Brent 法を用いて解を求めることとした。

以上の操作により凝縮器側の凝縮圧力を確定した後, 蒸発器側の 計算に戻る。凝縮器側の計算によって蒸発器入口エンタルピーが確 定しているため, この条件のもと, 蒸発器が出口エンタルピーを実 現できるか計算する。最低蒸発温度でも出口エンタルピーを実現で きない場合には蒸発器が過負荷状態となっている。蒸発温度を下げ る余地があれば, 温度を下げて蒸発器の処理熱量を増加させ, 再計 算を行う。この計算も凝縮圧力と同様, 蒸発温度を未知変数とした 範囲指定のある一次元関数誤差最小化問題であり，本研究では Brent 法によって解を求めることとした。

\section{5.メーカー技術資料によるパラメータ推定法}

本節では，メーカーから公開されている技術資料 ${ }^{(i 3)}$ に記載され ている条件と幾つかの仮定に基づき，モデルのパラメータを推定す る手法を提案する。

\section{1 モデル化対象システム}

図 6 にモデル化対象システムを示す。 $40.0 \mathrm{~kW}$ 級の室外機 1 台に 対して $4.5 \mathrm{~kW}$ 級室内機と $7.1 \mathrm{~kW}$ 級室内機がそれぞれ 3 台と $5.6 \mathrm{~kW}$ 級 室内機が 1 台接続されたシステムとした。室内機の合算能力は約 $40 \mathrm{~kW}$ であり，室外機能力との対応がとれている。

表 7 および表 8 に，モデルパラメー夕推定にあたって利用した室 外機および室内機の情報を示す。いずれも一般に公開されたメー カーの技術資料 ${ }^{\text {注 } 3)}$ から入手可能な項目である。な拉, 風量に関し

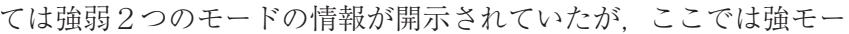
ドでの值を利用することとした。

\section{2 パラメータ推定法}

1) 冷凍サイクルの基準点の推定

まず，蒸発温度および過熱度を仮定することで定格運転時の圧縮 機入口状態を決定した（図 7 )。冷媒を R410A と仮定し, 定格運転 時の蒸発温度を $2^{\circ} \mathrm{C}$, 過熱度を $5{ }^{\circ} \mathrm{C}$ とた。蒸発温度 $2^{\circ} \mathrm{C}$ に対応す る冷媒圧力は $850 \mathrm{kPa}$ である。この圧力と温度に基づいてその他の

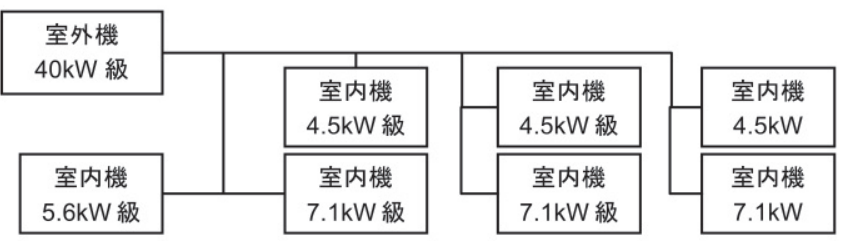

図6 モデル化対象の個別分散空調システム

表 7 技術資料記載の室外機情報

\begin{tabular}{c|l|l}
\hline 要素 & \multicolumn{1}{|c|}{ 情報内容 } & \multicolumn{1}{c}{ 定格性能值 } \\
\hline \hline \multirow{2}{*}{ 室外機 } & 能力 & $40 \mathrm{~kW}$ \\
\cline { 2 - 3 } & 消費電力 & $13.9 \mathrm{~kW}$ \\
\hline \multirow{3}{*}{ 圧縮機 } & 動力 & $2.0 / 4.5 / 4.5 \mathrm{~kW}$ \\
\cline { 2 - 3 } & ピストン押しのけ量 & $13.72 / 10.47 / 10.47 \mathrm{~m}^{3} / \mathrm{h}$ \\
\cline { 2 - 3 } & 回転数 & $6480 / 2900 / 2900 \mathrm{rpm}$ \\
\hline \multirow{2}{*}{ 凝縮器 } & ファン風量 & $210 \mathrm{~m}^{3} / \mathrm{min}$ \\
\cline { 2 - 3 } & ファン動力 & $0.75 \mathrm{~kW}$ \\
\hline
\end{tabular}

表 8 技術資料記載の室内機情報

\begin{tabular}{c|l|l}
\hline 機種 & \multicolumn{1}{|c|}{ 情報内容 } & \multicolumn{1}{c}{ 定格性能值 } \\
\hline \hline \multirow{2}{*}{$\begin{array}{c}4.5 \mathrm{~kW} \text { 級 } \\
\text { 室内機 }\end{array}$} & ファン風量 & $11.5 \mathrm{~m}^{3} / \mathrm{min}$ \\
\cline { 2 - 3 } & ファン動力 & $127 \mathrm{~W}$ \\
\cline { 2 - 3 } & 能力 & $4.5 \mathrm{~kW}$ \\
\hline \multirow{2}{*}{$\begin{array}{c}5.6 \mathrm{~kW} \text { 級 } \\
\text { 室内機 }\end{array}$} & ファン風量 & $15.0 \mathrm{~m}^{3} / \mathrm{min}$ \\
\cline { 2 - 3 } & ファン動力 & $127 \mathrm{~W}$ \\
\cline { 2 - 3 } & 能カ & $5.6 \mathrm{~kW}$ \\
\hline \multirow{2}{*}{$\begin{array}{c}7.1 \mathrm{~kW} \text { 級 } \\
\text { 室内機 }\end{array}$} & ファン風量 & $21.0 \mathrm{~m}^{3} / \mathrm{min}$ \\
\cline { 2 - 3 } & ファン動力 & $206 \mathrm{~W}$ \\
\cline { 2 - 3 } & 能カ & $7.1 \mathrm{~kW}$ \\
\hline
\end{tabular}

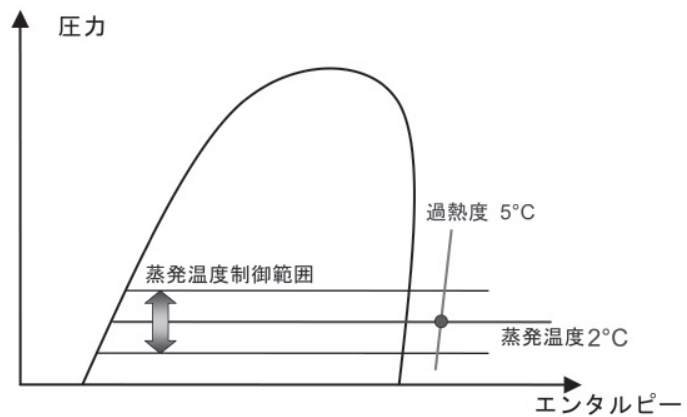

図 7 定格運転時に打ける圧縮機入口冷媒状態の推定

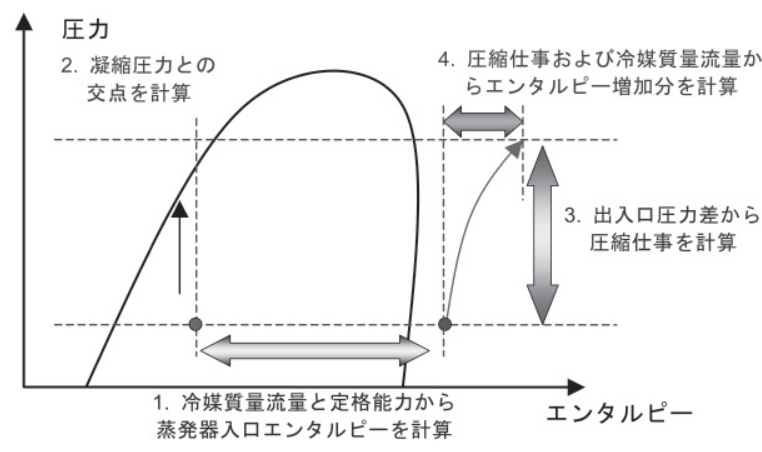

図 8 冷凍サイクル基準点の推定

$E_{C m p}=W / \eta_{e}$

$$
E_{\text {Aux }}=\frac{E_{\text {Cmp }}}{E_{\text {Cmp,rate }}} E_{\text {Aux }, \text { rate }}
$$

冷媒状態を計算すると，圧縮機入口冷媒状態は，エンタルピーが $427.4 \mathrm{~kJ} / \mathrm{kg}$, 密度が $31.5 \mathrm{~kg} / \mathrm{m}^{3}$, 比熱比 $(\kappa=C p / C v)$ が 1.313 となる。 
図 8 に定格条件下における冷凍サイクル基準点の推定法を示す。 まず，計算を単純化するため，3台の圧縮機を同等の能力を持つ 1 台の圧縮機に置き換えた。即ち, 単位回転数あたりのピストン押 しのけ量は, $\left(13.72+10.47+10.47 \mathrm{~m}^{3} / \mathrm{h}\right) / 6480 \mathrm{rpm} / 60=8.9146 \mathrm{E}^{-5} \mathrm{~m}^{3} /$ round となる。上記の通り, 圧縮機入口の冷媒密度は既知であるた め, ピストン押しのけ量および定格回転数と合わせ，冷媒質量流量 を計算することができる（式 6 )。本例の場合, $31.5 \mathrm{~kg} / \mathrm{m}^{3} \times 8.9146$ $\mathrm{E}^{-5} \mathrm{~m}^{3} /$ round $\times 6480 / 60 \mathrm{rps} \times 0.95=0.26 \mathrm{~kg} / \mathrm{s}$ となる。

次に, 室外機の定格能力 (本例の場合 $40 \mathrm{~kW}$ ), 質量流量, 蒸発器 出口エンタルピー（=圧縮機入口エンタルピー）に基づいて, 蒸発 器入口エンタルピーを逆算する。本例の場合, $427.4 \mathrm{~kJ} / \mathrm{kg}-40 \mathrm{~kW} /$ $0.26 \mathrm{~kg} / \mathrm{s}=274.4 \mathrm{~kJ} / \mathrm{kg}$ となる。 $\mathrm{R} 410 \mathrm{~A}$ 冷媒の凝縮圧力は $3000 \mathrm{kPa}$ 程 度であり, 凝縮圧力と蒸発器入口エンタルピーから凝縮器出口冷媒 状態を計算することができる。

一方，圧縮機出入口圧力差と圧縮仕事の理論式（式 4）から圧縮 仕事を計算することができ，本例の場合では $10.3 \mathrm{~kW}$ となる。技術 資料に記載された圧縮機動力 $(11 \mathrm{~kW})$ とほぼ一致していることが わかる。残差は機械効率（10.3/11.0=0.93）によるものとする（式 $9)$ 。また, 室外機全体としての消費電力 $(13.9 \mathrm{~kW})$ と圧縮機動力 $(11 \mathrm{~kW})$ との差は補機類による消費電力と推測され，これらに関し ては圧縮機の動力に比例すると仮定し, 式10で計算することとする。

既に求めた圧縮仕事量と冷媒質量流量との関係から圧縮機出口冷 媒エンタルピーを求めることができる（式 5 )。本例の場合, 圧縮 機入口冷媒エンタルピーが $427.4 \mathrm{~kJ} / \mathrm{kg}$ であるから, 圧縮機出口冷 媒エンタルピーは $427.4 \mathrm{~kJ} / \mathrm{kg}+10.3 \mathrm{~kW} / 0.26 \mathrm{~kg} / \mathrm{s}=469.4 \mathrm{~kJ} / \mathrm{kg}$ とな る。

以上により，定格条件下に扔ける冷凍サイクル基準点 4 点が推定 できる。

\section{2）熱交換器パラメータの推定}

室内機および室外機の入口空気条件は JIS B $8616^{14)}$ により定めら れており，室外機に関しては $35^{\circ} \mathrm{CDB}$ ，室内機に関しては $27^{\circ} \mathrm{CDB}$, $19^{\circ} \mathrm{CWB}$ である。冷房運転時の室外機は凝縮器として働き, 湿度は 問題とならないため，プログラム上は適当な值を設定しておく。

一方，冷媒の出入口条件は上記の通り既知である。冷媒質量流量 は, 凝縮器に関しては圧縮機通過流量と同じとし, 本例の場合は, $0.26 \mathrm{~kg} / \mathrm{s}$ となる。蒸発器の冷媒質量流量は, 表 8 に示した定格能 力と出入口エンタルピー差から逆算する。例えば $7.1 \mathrm{~kW}$ 級室内機の 場合, $7.1 \mathrm{~kW} /(427.4-274.4 \mathrm{~kJ} / \mathrm{kg})=0.04642 \mathrm{~kg} / \mathrm{s}$ となる。また, 風 量および定格能力については，表 8 に示したとおり，技術資料から 入手可能である。以上により, 熱交換器の出入口冷媒状態书よび空 気状態，風量および冷媒流量が与えられるため, 熱交換器の理論式 （式 7 , 式 8) を数值解として逆算することで, 熱交換器面積 $\times$ 熱 通過率 $K A$ を推定することができる。相ごとに異なる熱通過率 $K$ を 設定しても $A$ を逆算できるが，本例では $K_{s h}=K_{t p}=K_{s c}$ とした。

\section{6. モデルの精度検証}

5 節で行ったパラメータ推定により, 定格条件においてメーカー 技術資料の記述と一致する状態点を再現できる物理モデルを得るこ とができた。本節では，定格条件以外の条件下（外挿範囲）におけ るモデルの精度について検証した結果を示す。
表 $940 \mathrm{~kW}$ 級室外機の消費電力 $(\mathrm{kW})$ 特性

\begin{tabular}{c|c|c|c|c|c|c}
\hline & \multicolumn{7}{|c}{ 室内吸込空気温度 ${ }^{\circ} \mathrm{CWB}$} \\
\hline 外気温度 & 16 & 18 & 19 & 20 & 22 & 24 \\
\hline \hline $25^{\circ} \mathrm{CDB}$ & 7.34 & 9.08 & 10.0 & 11.0 & 11.6 & 11.7 \\
\hline $27^{\circ} \mathrm{CDB}$ & 7.84 & 9.70 & 10.7 & 11.8 & 12.1 & 12.2 \\
\hline $29^{\circ} \mathrm{CDB}$ & 8.36 & 10.4 & 11.4 & 12.5 & 12.6 & 12.7 \\
\hline $31^{\circ} \mathrm{CDB}$ & 8.91 & 11.1 & 12.2 & 13.0 & 13.1 & 13.2 \\
\hline $33^{\circ} \mathrm{CDB}$ & 9.49 & 11.8 & 13.0 & 13.5 & 13.6 & 13.7 \\
\hline $35^{\circ} \mathrm{CDB}$ & 10.1 & 12.6 & $\underline{13.9}$ & 14.0 & 14.1 & 14.2 \\
\hline $37^{\circ} \mathrm{CDB}$ & 10.7 & 13.4 & 14.4 & 14.5 & 14.6 & 14.7 \\
\hline $39^{\circ} \mathrm{CDB}$ & 11.4 & 14.3 & 14.9 & 14.9 & 15.1 & 15.2 \\
\hline \multicolumn{7}{|c|}{}
\end{tabular}

下線は定格条件

表10 $40 \mathrm{~kW}$ 級室外機の能力 $(\mathrm{kW})$ 特性

\begin{tabular}{c|c|c|c|c|c|c}
\hline & \multicolumn{7}{|c}{ 室内吸込空気温度 ${ }^{\circ} \mathrm{CWB}$} \\
\hline 外気温度 & 16 & 18 & 19 & 20 & 22 & 24 \\
\hline \hline $25^{\circ} \mathrm{CDB}$ & 32.2 & 37.4 & 40 & 42.6 & 44.7 & 45.7 \\
\hline $27^{\circ} \mathrm{CDB}$ & 32.2 & 37.4 & 40 & 42.6 & 44.1 & 45 \\
\hline $29^{\circ} \mathrm{CDB}$ & 32.2 & 37.4 & 40 & 42.4 & 43.4 & 44.4 \\
\hline $31^{\circ} \mathrm{CDB}$ & 32.2 & 37.4 & 40 & 41.8 & 42.8 & 43.7 \\
\hline $33^{\circ} \mathrm{CDB}$ & 32.2 & 37.4 & 40 & 41.1 & 42.1 & 43.1 \\
\hline $35^{\circ} \mathrm{CDB}$ & 32.2 & 37.4 & $\underline{40}$ & 40.5 & 41.5 & 42.4 \\
\hline $37^{\circ} \mathrm{CDB}$ & 32.2 & 37.4 & 39.3 & 39.8 & 40.8 & 41.8 \\
\hline $39^{\circ} \mathrm{CDB}$ & 32.2 & 37.4 & 38.7 & 39.2 & 40.2 & 41.1 \\
\hline
\end{tabular}

表11 モデルによる消費電力 $(\mathrm{kW})$ 計算結果

\begin{tabular}{c|c|r|r|r|r|r}
\hline & \multicolumn{7}{|c}{ 室内吸込空気温度 ${ }^{\circ} \mathrm{CWB}$} \\
\hline 外気温度 & \multicolumn{1}{|c|}{16} & 18 & \multicolumn{1}{c}{19} & \multicolumn{1}{c}{20} & \multicolumn{1}{c}{22} & \multicolumn{1}{c}{24} \\
\hline \hline $25^{\circ} \mathrm{CDB}$ & 7.07 & 8.84 & 9.67 & 10.7 & 11.5 & 11.5 \\
\hline $27^{\circ} \mathrm{CDB}$ & 7.65 & 9.47 & 10.5 & 11.5 & 12.0 & 12.0 \\
\hline $29^{\circ} \mathrm{CDB}$ & 8.29 & 10.3 & 11.3 & 12.2 & 12.4 & 12.4 \\
\hline $31^{\circ} \mathrm{CDB}$ & 8.86 & 11.0 & 12.1 & 12.8 & 13.1 & 13.1 \\
\hline $33^{\circ} \mathrm{CDB}$ & 9.47 & 11.7 & 12.9 & 13.5 & 13.6 & 13.6 \\
\hline $35^{\circ} \mathrm{CDB}$ & 10.1 & 12.4 & $\underline{13.9}$ & 14.1 & 14.1 & 14.1 \\
\hline $37^{\circ} \mathrm{CDB}$ & 10.9 & 13.4 & 14.4 & 14.6 & 14.6 & 14.6 \\
\hline $39^{\circ} \mathrm{CDB}$ & 11.6 & 14.4 & 15.0 & 15.0 & 15.0 & 15.0 \\
\hline \multicolumn{7}{c}{}
\end{tabular}

表12 未処理負荷

\begin{tabular}{c|c|c|c|c|c|c}
\hline & \multicolumn{7}{|c}{ 室内吸込空気温度 ${ }^{\circ} \mathrm{CWB}$} \\
\hline 外気温度 & 16 & 18 & 19 & 20 & 22 & 24 \\
\hline \hline $25^{\circ} \mathrm{CDB}$ & - & - & - & - & 0.14 & 1.15 \\
\hline $27^{\circ} \mathrm{CDB}$ & - & - & - & - & 0.36 & 1.26 \\
\hline $29^{\circ} \mathrm{CDB}$ & - & - & - & - & 0.31 & 1.31 \\
\hline $31^{\circ} \mathrm{CDB}$ & - & - & - & - & 0.81 & 1.71 \\
\hline $33^{\circ} \mathrm{CDB}$ & - & - & - & - & 0.90 & 1.90 \\
\hline $35^{\circ} \mathrm{CDB}$ & - & - & - & 0.07 & 1.07 & 1.97 \\
\hline $37^{\circ} \mathrm{CDB}$ & - & - & - & 0.22 & 1.22 & 2.22 \\
\hline $39^{\circ} \mathrm{CDB}$ & - & - & - & 0.38 & 1.38 & 2.28 \\
\hline
\end{tabular}

室内機吸込空気温度条件および外気温度に対する機器特性に関し ては, メーカーの技術資料で公開されているため, この特性と比較 することでモデルの精度検証を行った。表 9 および表10にモデル化 対象である $40 \mathrm{~kW}$ 級室外機の特性を示す。

表10に示す負荷をモデルの入力として与え, 消費電力の計算を 行った。回転数は10 100\%の範囲で可変とし, 蒸発温度は一定と した。表11および図 9 にモデルによる消費電力計算結果を示す。パ ラメー夕推定に用いた定格条件以外の条件下においても精度を保っ た計算ができていることがわかる。誤差率は，外気 $25^{\circ} \mathrm{CDB}$, 室内 $16^{\circ} \mathrm{CWB}$ の条件で最大となり，約 $3.7 \%$ となった。ただし，表 $11 の$ 
網がけの条件では回転数が最大となり，表 12 に示すように，最大で $5.5 \%$ 程度の未処理負荷が発生した。この原因としては以下の理由 が考えられる。

式 7 からわかるように，室内負荷が大きくなった場合の機器の対 応としては対数平均温度差 $\Delta \theta$ を向上させるという方法, あるいは 冷媒質量流量 $G_{r e f}$ を向上させるという方法が挙げられる。前者の方 法をとるためには低圧を下げて蒸発温度を低下させる必要がある。 一方, 後者の方法をとるためには低圧を上げて圧縮機入口での冷媒 密度を向上させ, 冷媒循環量を向上させる必要がある。負荷が小さ く, かつ吸込空気温度が低い場合には冷媒循環量よりも温度差の影 響が交換熱量に対して支配的になるため，蒸発温度を下げることが 有利だと考えられる。一方，負荷が大きく，かつ吸込空気温度が高 い場合には冷媒循環量の影響が支配的となるため，蒸発温度をあげ ることが有利だと考えられる。本モデルでは前者の状態に対応でき る様に, 図 5 に示される様に蒸発温度が低い側が最も能力がでるこ とを仮定した収束計算を捛こなっている。従って，表11網がけの様 に，高負荷·高吸込温度の場合には未処理負荷が生じる結果となる。 この問題に対応するためには, 蒸発温度を上げるか下げるか, いず れが有利かを判定する処理を追加する必要がある。

\section{7.まとめ}

本研究では, 個別分散空調システムの定量的性能評価を可能とす ることを目的に，特性式よりも外挿可能性において優れている物理 式に基づいたモデルを開発した。特に，従来の物理モデルが抱えて いた問題点である計算速度の遅さと, 煩雑なパラメー夕設定作業を 解決するための方法を提案した。

1 ）計算速度の向上のため, ニューラルネットワークを用いた泠媒 物性值近似法を提案した。R $410 \mathrm{~A}$ 冷媒に手法を適用したとこ ろ，REFPROP と比較して飽和線上の冷媒状態に関しては100 倍以上，その他の領域に関しては400倍以上の速度向上が確認 できた。また, 平均誤差率は, 温度, 密度ともに $0.2 \%$ 未満と なった。

2 ）室内機の負荷を入力, 消費エネルギー量を出力とする空調設備 のエネルギーシミュレーション用の冷凍サイクル計算モデルを 提案した。また, メーカーから開示されている定格運転時の機 器性能をもとに, 提案した冷凍サイクル計算モデルのパラメー 夕設定を行うための方法を示した。

3 ）構築したモデルに, 定格以外の条件を入力として与え, 出力精 度を評価した。室内吸込空気温度条件および外気温度条件を摇 らした場合の消費エネルギー量を計算し，技術資料に開示され ている機器特性と比較したところ, 最大の誤差率は $3.7 \%$ となっ た。

\section{謝辞}

本研究を遂行するにあたり, 鹿島建設株式会社 平岡雅哉様, ダ イキン工業株式会社 加井隆重様に多くのご協力を頂きました。ま た，モデルの作成に関しては，早稲田大学基幹理工学部 河合素直 教授に助言を頂きました。パラメータ推定方法等については横浜国 立大学 中邨 隆先生に多くのご意見を頂きました。本研究の一部 は科学研究費 (基盤研究(A) 19206063 ：ソフトコンピューティング

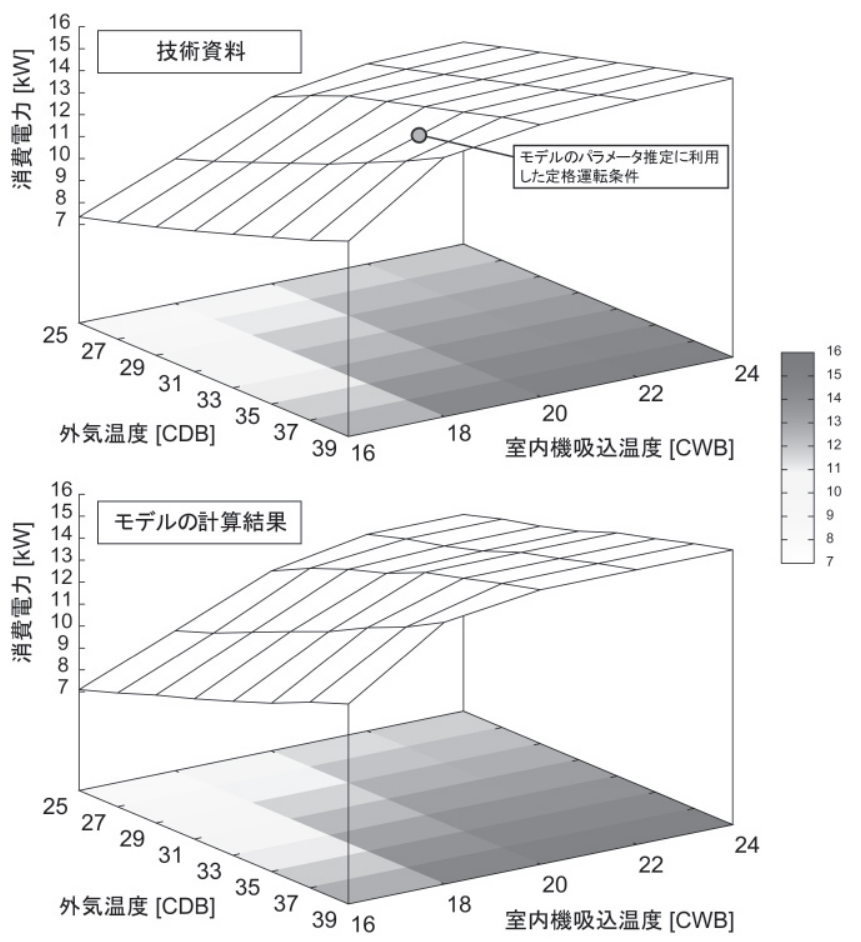

図 9 モデルによる消費電力 $(\mathrm{kW})$ 計算結果

を核とした建築・人間・設備システムの最適化の研究）により実施 しました。ここに記して謝意を示します。

\section{記号一覧}

$A$ : 伝熱面積 $\left[\mathrm{m}^{2}\right], C p$ : 定圧熱容量 $[\mathrm{J} /(\mathrm{kg} \mathrm{K})], C v$ : 定積熱容量 $[\mathrm{J} /(\mathrm{kg} \mathrm{K})]$ $E$ : 消費電力 $[\mathrm{kW}], G$ : 冷媒質量流量 $[\mathrm{kg} / \mathrm{sec}], H$ : 冷媒エンタルピー $[\mathrm{kJ} / \mathrm{kg}]$ $K:$ 熱通過率 $\left[\mathrm{kW} / \mathrm{K}-\mathrm{m}^{2}\right], N$ : 圧縮機回転数 $[\mathrm{rps}]$

$P$ : 冷媒圧力 $[\mathrm{kPa}], Q:$ 流量とエンタルピーから計算した交換熱量 $[\mathrm{kW}$

$Q^{\prime}$ : 対数平均温度差から計算した交換熱量 $[\mathrm{kW}], R$ : 伝熱面積割合 $[-]$

$T$ : 冷媒温度 $[\mathrm{K}]$, vol : ピストン吐出し量 $\left[\mathrm{m}^{3} / \mathrm{sec}\right]$

$W:$ 圧縮機圧縮仕事 $[\mathrm{kW}], w$ : 素子の結合加重

$x$ : 素子への入力, $y$ : 素子からの出力

$\varepsilon$ : 収束計算の絶対許容誤差 $[-], \eta_{v}$ : 体積効率 $[-], \eta_{e}$ : 機械効率 $[-], \theta$ : 閾值 $\kappa$ : 比熱比 $[-], \rho:$ 密度 $\left[\mathrm{kg} / \mathrm{m}^{3}\right], \sigma$ : 中間層素子数, $\tau$ : 入力層素子数

\section{添字}

air : 空気, $A u x$ : 補機, $C m p$ : 圧縮機, $C n d$ : 凝縮器

$E v p:$ 蒸発器, $e v p:$ 蒸発温度, in : 入口, $\max :$ 最大, $\min :$ 最小 out : 出口, rate : 定格運転時, ref : 冷媒, sc : 過冷却域, $s h$ : 過熱域 $s l$ : 飽和液線上, $s v$ : 飽和蒸気線上, $t p:$ 二相域

\section{参考文献}

1）ヒートポンプ・蓄熱白書, 財)ヒートポンプ・蓄熱センター, 第吕部統計編, 2007

2）宇田川光弘：個別式空調機のシミュレーションモデル, 空気調和・衛生 工学会学術講演会講演論文集, pp.593-596, 1987.10

3）江草恒則，下田吉之，山崎政人，水野 稔：小規模建物における個別熱 源システムのエネルギー消費特性に関する研究（第 1 報）モデルの概要 と建物条件によるシステム性能への影響, 空気調和・衛生工学会学術講 演会講演論文集，pp.105-108，2001

4）山崎政人，江草恒則，下田吉之，水野 稔：小規模建物に扔ける個別熱 源システムのエネルギー消費特性に関する研究（第 2 報）実験計画法に よるシステム性能の要因効果の検討, 空気調和 - 衛生工学会学術講演会 講演論文集，pp.109-112，2001

5）山下周一, 赤司泰義, 渡辺俊行, 尾崎明仁, 井崎智伸：個別分散空調シ ステムのエネルギーシミュレーション，日本建築学会大会学術講演梗概 集, D-II, pp.1025-1026, 2003 
6）㽞崎史武：冷凍サイクルのダイナミックシミュレーション（R407C）, 冷 凍 第78巻 第909号, pp.35-40, 2003.07

7）宮本洋平, 茴谷至誠, 植草常雄, 河合素直 : 年間冷房型空冷パッケージ 空調機に関する検討, 空気調和・衛生工学会学術講演会講演論文集, pp.165-172, 1996.09

8) Eric W. Lemmon, Mark O. Mclinden, Marcia L. Huber: NIST Reference Fluid Thermodynamic and Transport Properties - REFPROP Users Guide

9) Guo Liang Ding, Zhigang Wu, Kaijian Wang and Masaharu Fukaya: Extension of the applicable range of the implicit curve-fitting method for refrigerant thermodynamic properties to critical pressure, International Journal of Refrigeration, pp.1-15, 2006

10) A. C. Cleland: Polynomial curve-fits for refrigerant thermodynamic properties: extension to include R134a, Int. J. Refrigeration 17(4), pp.245-249, 1994

11) W. W. S. Charters and H A. Sadafi: Saturation property equations for R22, Int. J. Refrigeration 10(2), pp.103-104, 1987

12) Corberan J. M., Gonzalvez J., Fuentes D: Calculation of refrigerant properties by linear interpolation of bidimensional meshes, http://www.imst-art.com/ficherosdesc/interpolation.pdf (accessed 200901-20)

13) Cybenko G.: Approximation by superposition of a sigmoidal function, Math. Control Signals Systems, 2, pp.303-314, 1989

14）JIS B8616：2006パッケージエアコンディショナ, 日本規格協会, 2006. 03.25

注

注 1 ）評価に用いた計算機の性能は, $\mathrm{CPU}: 2.93 \mathrm{GHz}$ ，メモリ：512MB, OS：Windows XPである。

注 2 ）図には主要な計算フローのみを記しており，実際のプログラムには, さらに細かい分岐等が存在する。本研究で開発したプログラムのソース コードは全て, General Public Licenseのもと, Web (http://gf.hvacsimulator. net）で公開しているので, 必要に応じて参照されたい。

注 3 ）http://www.daikin.co.jp/等からダウンロード可能な技術資料

（2009年 6 月10日原稿受理，2009年11月30日採用決定） 